\title{
A simple and an efficient approach to the synthesis of a specific tautomer of 1,3-thiazinones and 1,3-oxazinones
}

\author{
Hassan Sheibani $^{\mathbf{a}^{*}}$, Mohammad Hossein Mosslemin ${ }^{\mathrm{b}}$, Soheila Behzadi ${ }^{\mathrm{b}}$, \\ Mohammad Reza Islami ${ }^{a}$, Habibollah Foroughi, and Kazem Saidi ${ }^{a}$ \\ ${ }^{a}$ Department of Chemistry, Shahid Bahonar University of Kerman, Kerman 76169, Iran \\ ${ }^{b}$ Department of Chemistry, Islamic Azad University of Yazd, Yazd, Iran \\ E-mail: hsheibani@mail.uk.ac.ir
}

(received 04 Aug 05; accepted 07 Sep 05; published on the web 09 Sep 05)

\begin{abstract}
A specific tautomer of 1,3-thiazinone and 1,3-oxazinone derivatives were prepared in a one step procedure from condensation of chlorocarbonyl ketenes (CCKs) such as (chlorocarbonyl)phenyl ketene and (chlorocarbonyl)benzyl ketene with thiobenzamide, thioacetamide, cinnamide , benzamide, 2-phenylacetamide and acetamide. This method provides an easy route to prepare 2,5-disubstituted 4-hydroxy-1,3-thiaizin-6-ones and 2, 5-disubstituted 4-hydroxy 1, 3-oxazin-6ones in good to excellent yields in a short experimental time.
\end{abstract}

Keywords: Specific tautomer, chlorocarbonyl ketenes (CCKs), 1,3-thiazinone, 1,3-oxazinone

\section{Introduction}

The study of $\alpha$-oxoketenes (acyl ketenes) and their reactions, were investigated because these compounds contain two active functional groups. $\alpha$-Oxoketenes are highly reactive molecules which usually cannot be isolated under ordinary reaction conditions, although several examples have been reported that the ketene bands of the $\alpha$-oxoketenes have been detected at low temperature by infrared spectroscopy technique. ${ }^{1-4}$

However, some of these ketenes can be stabilized both sterically and electronically. For example ketenes containing carboxylic acid derivatives such as chlorocarbonyl ketenes (CCKs) are extraordinarily stable. These ketenes are currently of considerable interest, not only because

of mechanistic and theoretical considerations, ${ }^{5}$ but also due to their use as synthetic building blocks in the preparation of organic compounds. ${ }^{6,7}$ Chlorocarbonyl ketenes have been found to be a very effective 1,3-bielectrophile reagents and react with a wide variety of nucleophiles under a mild experimental conditions, and have been used mainly for the synthesis of five-and six-membered heterocycles functionalized with oxo and hydroxyl groups in 1,3-positions. ${ }^{8,9}$ 
We have recently reported the reaction of (chlorocarbonyl)phenyl ketene with 1,3-diketones as 1,3-dinucleophiles to produce 2-pyrone derivatives. ${ }^{10}$ The cycloaddition reaction of (chlorocarbonyl) ketenes with dinucleophiles such as hydrazones, ${ }^{11}$ oximes, ${ }^{12}$ imidazoles and substituted arylthioamides were reported in the literature. ${ }^{13-15}$ In continuing our interest in the synthesis of heterocyclic compounds, now we wish to report a one-pot synthesis of a specific tautomer of 1,3-thiazinone and 1,3-oxazinone derivatives. However, the attempted reaction of (chlorocarbonyl)phenyl ketene and (chlorocarbonyl)benzyl ketene with several N-unsubstituted amides and thioamides at ambient temperature or even in boiling solvent such as dry THF have been mostly unsuccessful. Therefore the reactions were performed in a boiling solvent such as toluene or xylene. The simplicity and efficient one-pot procedure is one aspect of particular interest, in comparison to the other multi-step methods. On the other hand, readily available starting materials such as (chlorocarbonyl)phenyl ketene and (chlorocarbonyl)benzyl ketene, ${ }^{16}$ shorten experimental time, and high yield of the final products are the other advantages of this method.

\section{Results and Discussion}

1,3-Thiazinones exist in three tautomeric forms (I, II, and III). It is well known that Nunsubstituted thioamides react with malonic acid derivatives or malonic acid in the presence of dehydrating agents such as $\mathrm{POCl}_{3}, \mathrm{PCl}_{5}$, and acetic acid anhydride to yield only $4 \mathrm{H}-1,3$-thiazin4,6(5H)-di-ones, I. ${ }^{17}$ The reaction of carbon suboxide $\left(\mathrm{C}_{3} \mathrm{O}_{2}\right)$ with $\mathrm{N}$-unsubstituted thioamides such as thioacetimide gives 6-hydroxy-4-H-1,3-thiazin-4-one derivatives III. ${ }^{18}$
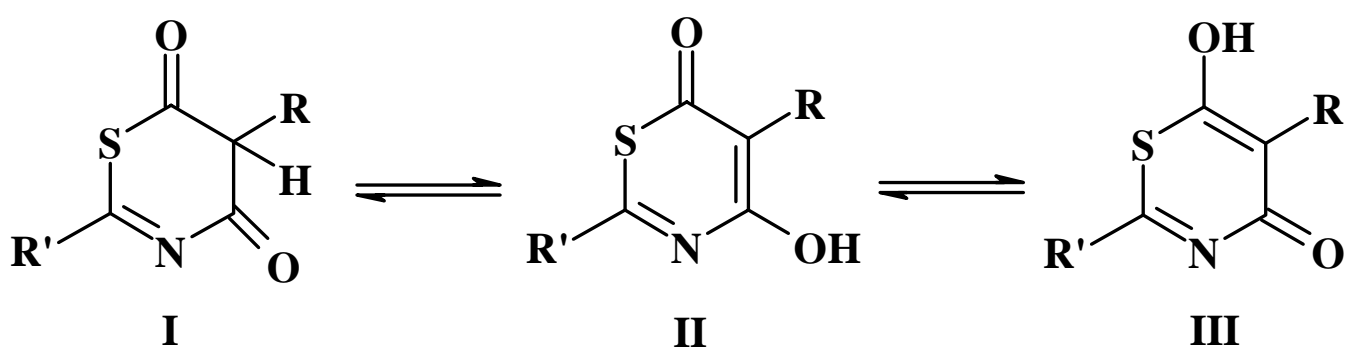

\section{Scheme 1}

In the present protocol as exhibited in scheme 2 the cycloaddition of chlorocarbonyl ketenes 1a-b with N-unsubstituted thioamides 2a-b only afforded 4-hydroxy-2,5-disubstituted-1,3thiazin-6-ones (II) as a specific tautomer of 1,3-thiazinone, in boiling dry toluene as a solvent. 


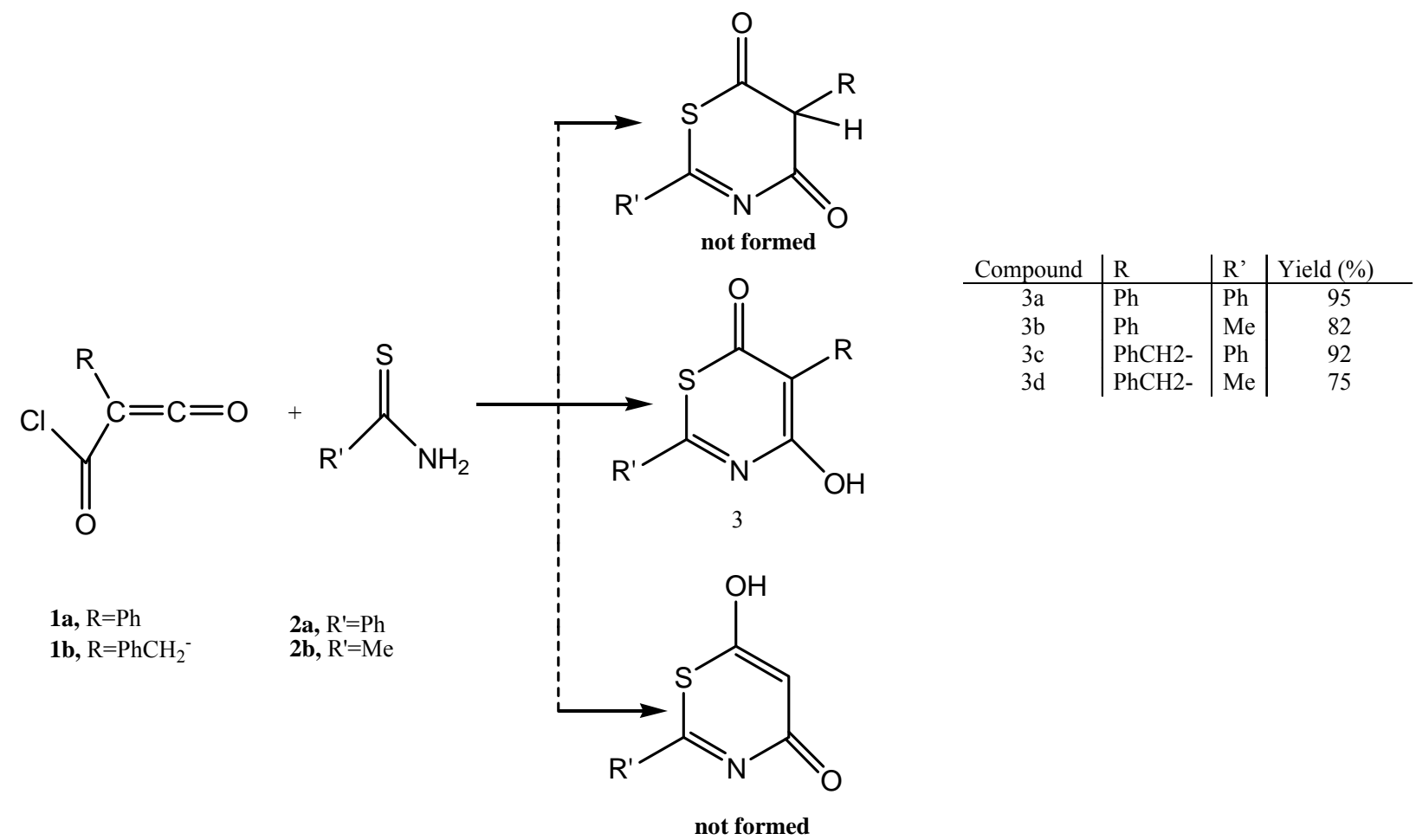

\section{Scheme 2}

In our investigation it was found that the reaction of $\mathrm{N}$-unsubstituted $\alpha, \beta$-unsaturated aliphatic amides or aromatic amides such as amides $\mathbf{4 a}$ and $\mathbf{4 b}$ with chlorocarbonyl ketenes gave 4-hydroxy-1,3-oxazin-6-one, 5 as the only product. (Scheme 3).

The same reaction with $\mathrm{N}$-unsubstituted aliphatic amides such as $\mathbf{6 a}$ and $\mathbf{6 b}$ afforded a mixture of two tautomers of corresponding 1,3-oxazinones (Scheme 4). 


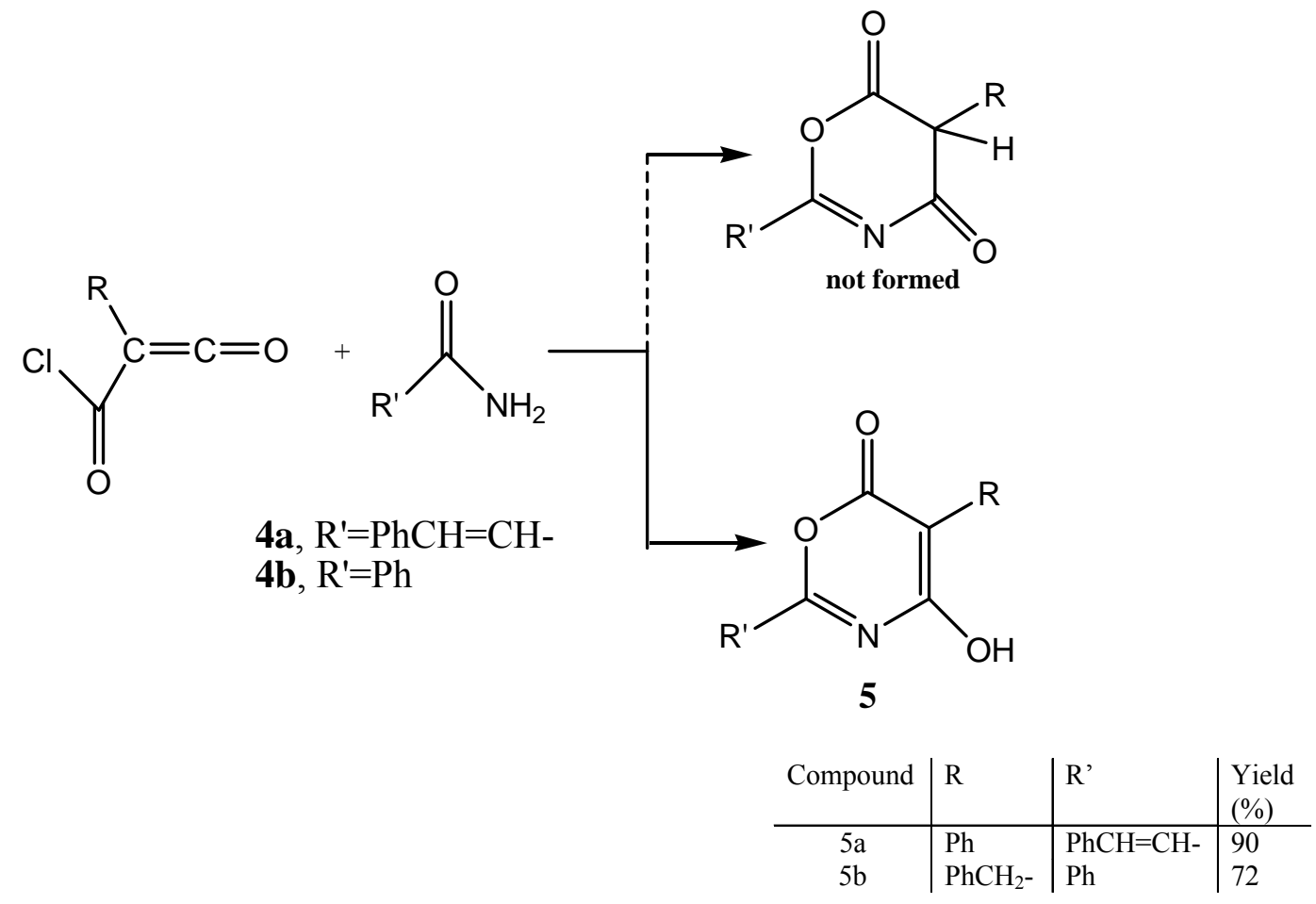

Scheme 3<smiles>[R]C(=O)C(=O)Cl</smiles>

\begin{tabular}{c|c|c|c} 
Compound & $\mathrm{R}$ & $\mathrm{R}^{\prime}$ & Yield (\%) \\
\hline $7 \mathrm{a}$ & $\mathrm{Ph}$ & $\mathrm{PhCH}_{2-}$ & 76 \\
$7 \mathrm{~b}$ & $\mathrm{Ph}$ & $\mathrm{Me}$ & 70
\end{tabular}

Scheme 4 
It is not clear to us why the products of the cycloaddition reaction of chlorocarbonyl ketenes with $\mathrm{N}$-unsubstituted $\alpha, \beta$-unsaturated amides or aromatic amides are different from the products of the cycloaddition reaction of chlorocarbonyl ketenes with $\mathrm{N}$-unsubstituted aliphatic amides. As it is shown (Scheme 2, 3 and 4) N-unsubstituted aliphatic amides produce mixture of two tautomers, while $\alpha, \beta$-unsaturated amides or aromatic amides give different tautomers. Apparently the conjugation of the 1,3-oxazinone ring with $\alpha, \beta$-unsaturated parts of the amides or aromatic rings of the amides might play an important role in these reactions.

Thus the cycloaddition reactions presented in schemes 2 and $\mathbf{3}$ accomplished by mixing the equimolar quantities of (chlorocarbonyl) ketenes and thioamides or amides in a dry boiling solvent. On the basis of our results, a plausible mechanism has been proposed for the reactions of chlorocarbonyl ketenes ${ }^{19}$ to yield 1,3-thiazinone and 1,3-oxazinone derivatives, as shown in scheme 5. However, the formation of compounds 3a-d, 5a-b and 7a-b can be explained by tautomerization of A to give small amount of intermediate B at high temperature. Attack of the $\mathrm{SH}$ as a good nucleophile ${ }^{20}$ or $\mathrm{OH}$ groups of the latter onto the acyl chloride of ketene, followed by cyclization of intermediate $\mathrm{C}$ and finally by proton shift from nitrogen to the oxygen atom. The final product was produced and was further characterized.

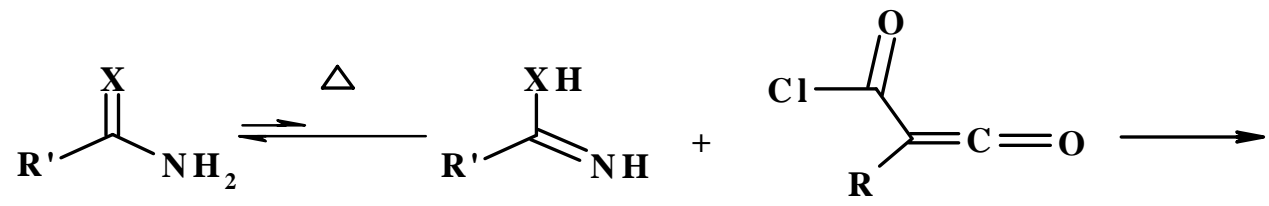

A

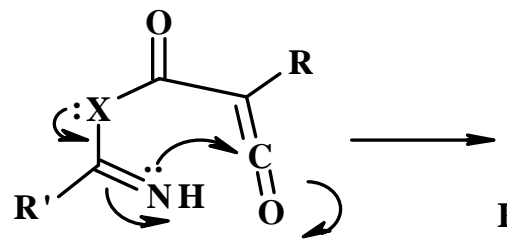

C
B

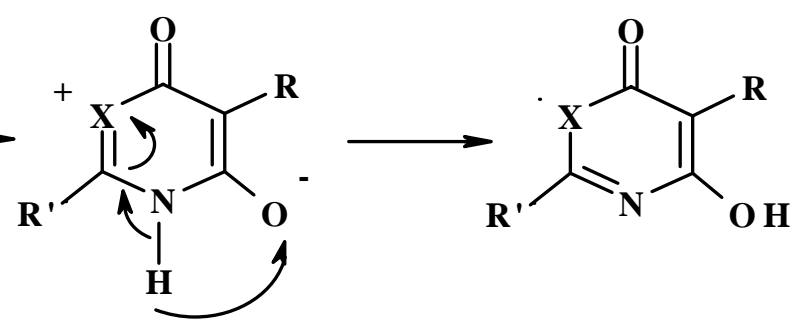

$$
\mathbf{X}=\mathbf{S}, \mathbf{O}
$$

The structures of compounds 3a-d, 5a-b and 7a-b were deduced from their elemental analyses and their IR, high-field ${ }^{1} \mathrm{H}$ and ${ }^{13} \mathrm{C}$ NMR spectra. The ${ }^{1} \mathrm{H}$ NMR and ${ }^{13} \mathrm{C}$ NMR spectra of 1, 3-thioxazinones 3a-d and 1,3-oxazinones 5a-d exhibited only one tautomer. Based on the ${ }^{1} \mathrm{H}$ NMR and ${ }^{13} \mathrm{C}$ NMR a mixture of two tautomers obtained from the reaction of aliphatic Nunsubstituted amides such as acetamide and phenyl acetamide with (chlorocarbonyl)phenyl ketene. Quantitative analysis of mixtures is achieved by evaluating the integration peaks of ${ }^{1} \mathrm{H}$ NMR spectra.

The ${ }^{1} \mathrm{H}$ NMR spectrum of 3a indicated two kinds of proton signals related to two different aromatic rings along with one signal quite downfield $(\delta 12.51 \mathrm{ppm})$ which is the $\mathrm{OH}$ proton of 
the enol form. The ${ }^{13} \mathrm{C}$ NMR and mass spectra of compound 3a are also in accordance with the proposed structure. The tautomer $\mathbf{I}$ is ruled out because in the high field ${ }^{1} \mathrm{H}$ NMR spectra of compounds 3a-d, the chemical shifts due to the methine proton were not detected. The ${ }^{13} \mathrm{C}$ NMR spectrum of $\mathrm{C}=\mathrm{O}$ attached to the sulfur atom revealed at about $\delta 180 \mathrm{ppm}$, whereas the carbon number 6 attached to sulfur (tautomer No. III) should revealed at approximately $\delta 160-170 \mathrm{ppm}$. Ziegler and coworkers, have reported 36\% yield of 4-hydroxy-2,5-diphenyl-6H-1,3-thiazin-6one 3a by treating phenyl malonic acid and $\mathrm{PCl}_{3}$ with thiobenzamide at $80{ }^{\circ} \mathrm{C} .{ }^{21}$ On the bases of these information the tautomer No II was formed as the only product. In general all of the spectral data support the structures of compounds 3a-d. The ${ }^{1} \mathrm{H}$ NMR spectrum of 5a showed four different kinds of proton signals. One signal at $(\delta 7.85 \mathrm{ppm})$ which was identified as $\beta$ olefinic proton of styryl group appear as a doublet $\left({ }^{3} \mathrm{~J}_{\mathrm{HH}}=15 \mathrm{~Hz}\right)$, the other doublet signal appears at $\delta=6.85 \mathrm{ppm}$ due to $\alpha$ - olefinic proton of styryl group $\left({ }^{3} \mathrm{~J}_{\mathrm{HH}}=15 \mathrm{~Hz}\right)$ and a multiplet $(\delta=7.79$ $7.23)$ for the aromatic protons $(10 \mathrm{H})$ along with one signal quite downfield $(\delta 12.62 \mathrm{ppm})$ which is the proton of enol $\mathrm{OH}$. The ${ }^{13} \mathrm{C}$ NMR spectrum of $5 \mathbf{a}$ displayed 14 distinct resonances in agreement with the proposed structure. The ${ }^{1} \mathrm{H}$ NMR and ${ }^{13} \mathrm{C}$ NMR spectra of $5 \mathbf{b}$ are similar to those of 5a, except for the presence of a peak due to $\mathrm{CH}_{2}$ group, and the absence of signals due to olfenic region. The ${ }^{1} \mathrm{H}$ and ${ }^{13} \mathrm{C}$ NMR spectroscopic data for compounds $7 \mathbf{a}-\mathbf{b}$ are also consistent with the presence of two tautomers. The ${ }^{1} \mathrm{H}$ NMR spectrum of compound 7 indicated five kinds of proton signals in agreement with the mixture of 7(I)a and 7(II)b.

\section{Experimental Section}

General Procedures. Thioacetamide, thiobenzamide, benzamide, cinnamide, 2-phenylacetamide, acetamide, phenyl malonic acid and benzylmalonic acid were obtained from Merck Chemical Co. and were used without further purification. Melting points were measured on a Gallenkamp melting point apparatus and are uncorrected. IR spectra were measured on a Mattson 1000 FT-IR spectrometer. The proton and carbon NMR spectra were recorded with a BRUKER DRX-500 AVANCE spectrometer at 500 and $125.77 \mathrm{MHz}$, respectively. Mass spectra were recorded on a MS-QP2000A Shimadzu mass spectrometer operating at an ionization potential of $70 \mathrm{eV}$. Elemental analyses were performed by National Iranian Oil Company lab (Tehran) using a Heracus CHN-O-Rapid analyzer.

\section{4-Hydroxy-2-5-diphenyl-6H-1, 3-thiazin-6-one (3a). General procedure (3a-d)}

To a stirred solution of $0.27 \mathrm{~g}$ thiobenzamide $(2 \mathrm{mmol})$ in $20 \mathrm{~mL}$ dry boiling toluene, a mixture of $0.36 \mathrm{~g}$ (chlorocarbonyl)phenyl ketene $(2 \mathrm{mmol})$ in $5 \mathrm{ml}$ dry THF was added dropwise over 2 min. Compound 3a was formed immediately as a yellow precipitate. The reaction mixture was cooled and the solid product was collected and recrystallized from dry ethyl acetate hexane. 0.53 g. yellow crystals. $95 \%$ yield, $\mathrm{mp} 228-230{ }^{\circ} \mathrm{C}$; lit. $\mathrm{mp} .218 .{ }^{21} \mathrm{MS}, \mathrm{m} / \mathrm{z}$ (relative intensity \%): 281 (63 parent peak), 253 (100 base peak), 145 (46), 121 (72), 104 (62), 89 (50), 77 (30). IR (KBr): 
3200 (broad peak, OH), $1605(\mathrm{C}=\mathrm{O}), 1565(\mathrm{C}=\mathrm{N}) \mathrm{cm}^{-1} .{ }^{1} \mathrm{H}$ NMR (DMSO): $\delta 12.51(1 \mathrm{H}, \mathrm{s}, \mathrm{OH})$, $8.18-7.11\left(10 \mathrm{H}, \mathrm{m}\right.$, arom). ${ }^{13} \mathrm{C}$ NMR (DMSO): $\delta 178.65(\mathrm{C}=\mathrm{O}), 172.10$ and $166.63(2 \mathrm{C})$, 135.71, 131.48, 130.82, 129.82, 129.33, 127.65, 127.08 and 126.95 (8C, arom), $104.55\left(\mathrm{C}_{5}\right)$. Anal. Calcd. for $\mathrm{C}_{16} \mathrm{H}_{11} \mathrm{NO}_{2} \mathrm{~S}$ : C, 68.32; H, 3.91; N, $4.98 \%$. Found : C, 68.30; H. 4.15; N; $4.90 \%$.

4-Hydroxy-2-methyl-5-phenyl-6H-1,3-thiazin-6-one(3b). 0.36 g. Pale yellow crystals, yield $82 \%$, mp 145-147 ${ }^{\circ} \mathrm{C} . \mathrm{MS}, \mathrm{m} / \mathrm{z}$ (relative intensity \%): 219 (100, parent peak and base beak), 191 (45), 145 (30), 118 (38). IR (KBr): 3230 (broad peak, OH), $1633(\mathrm{C}=\mathrm{O}), 1595(\mathrm{C}=\mathrm{N}) \mathrm{cm}^{-1} .{ }^{1} \mathrm{H}$ NMR (DMSO): $\delta 12.11(1 \mathrm{H}, \mathrm{s}, \mathrm{OH}), 7.59-7.46(5 \mathrm{H}, \mathrm{m}$, arom), 2.77 (3H, s, methyl protons). ${ }^{13} \mathrm{C}$ NMR (DMSO): $\delta 184.88(\mathrm{C}=\mathrm{O}), 180.36$ and $171.26(2 \mathrm{C}), 136.18,135.57,132.56,131.95$ (4C, arom), $109.66\left(\mathrm{C}_{5}\right), 32.70\left(\mathrm{CH}_{3}\right)$. Anal. Calcd. for $\mathrm{C}_{11} \mathrm{H}_{9} \mathrm{NO}_{2} \mathrm{~S}: \mathrm{C}, 60.27 ; \mathrm{H}, 4.10 ; \mathrm{N}$, $6.39 \%$. Found : C, 60.18; H. 4.15; N; $6.28 \%$.

5-Benzyl-4-hydroxy-2-phenyl-6H-1,3-thiazin-6-one (3c). 0.54 g. Yellow crystals, yield 92\%, mp 218-220 ${ }^{\circ} \mathrm{C}$; lit. mp. $220 .{ }^{21} \mathrm{MS}, \mathrm{m} / \mathrm{z}$ (relative intensity \%): 295 (100, parent peak and base beak), 267 (48), 131 (60), 91 (77). IR (KBr): 3170 (broad peak, OH), $1600(\mathrm{C}=\mathrm{O})$, 1572(C=N) cm ${ }^{-1} .{ }^{1} \mathrm{H}$ NMR (DMSO): $\delta 12.50(1 \mathrm{H}, \mathrm{s}, \mathrm{OH}), 7.98-7.11(10 \mathrm{H}, \mathrm{m}$, arom), $3.77(2 \mathrm{H}$, s, benzyl protons). ${ }^{13} \mathrm{C}$ NMR (DMSO): $\delta 179.30(\mathrm{C}=\mathrm{O}), 171.27$ and $167.13(2 \mathrm{C}), 139.97,135.81$, 133.13, 129.53, 128.89, 128.30, 126.85, 125.87 (8C, arom), $103.57\left(\mathrm{C}_{5}\right), 28.11\left(\mathrm{CH}_{2}\right)$. Anal. Calcd. for $\mathrm{C}_{17} \mathrm{H}_{13} \mathrm{NO}_{2} \mathrm{~S}$ : C, 69.15; H, 4.40; N, 4.74 \%. Found : C, 69.02; H. 4.42; N; $4.65 \%$.

5-Benzyl-4-hydroxy-2-methyl-6H-1,3-thiazin-6-one (3d). 0.35 g. pale yellow crystals, yield 75\%, mp 141-143 ${ }^{\circ} \mathrm{C} . \mathrm{MS}, \mathrm{m} / \mathrm{z}$ (relative intensity \%): 233 (15, parent peak), 191 (42), 104 (100, base peak), 91 (44), 60 (48). IR (KBr): 3150 (broad peak, OH), $1632(\mathrm{C}=\mathrm{O}), 1595(\mathrm{C}=\mathrm{N}) \mathrm{cm}^{-1}$. ${ }^{1} \mathrm{H}$ NMR (DMSO): $\delta 12.54(1 \mathrm{H}, \mathrm{s}, \mathrm{OH}), 7.30--7.10(5 \mathrm{H}, \mathrm{m}$, arom $), 3.69(2 \mathrm{H}$, s, benzyl protons), 2.53(s, methyl protons). ${ }^{13} \mathrm{C}$ NMR (DMSO): $\delta 179.83(\mathrm{C}=\mathrm{O}), 174.94$ and 166.89(2C), 140.13, 128.72, 128.30, 125.78 (4C, arom), $102.73\left(\mathrm{C}_{5}\right), 32\left(\mathrm{CH}_{3}\right), 27.64\left(\mathrm{CH}_{2}\right)$. Anal. Calcd. for $\mathrm{C}_{12} \mathrm{H}_{11} \mathrm{NO}_{2} \mathrm{~S}$ : C, 61.80; H, 4.72; N, $6.00 \%$. Found : C, 61.57; H. 4.70; N; $5.82 \%$.

2-(2-Phenylvinyl)-5-phenyl-4-hydroxy-6H-1,3-oxazin-6-one (5a). General procedure (5a-b and 7a-b). To a boiling solution of cinnamide $(0.29 \mathrm{~g}, 2 \mathrm{mmol})$ in $15 \mathrm{ml}$ of dry xylene was added (chlorocarbonyl)phenyl ketene $(0.36 \mathrm{~g}, 2 \mathrm{mmol})$. The reaction mixture was cooled and a precipitate formed instantly. The solid product was collected and recrystallized from dry ethyl acetate-hexane. $0.52 \mathrm{~g}$. orange crystals, yield $90 \%, \mathrm{mp} 217-219{ }^{\circ} \mathrm{C}$. MS, m/z (relative intensity \%): 291(100, parent peak and base peak), 263 (25), 131 (60), 118 (30), 77(15). IR (KBr): 3180 (broad peak, OH), 17410, $1650 \mathrm{~cm}^{-1} .{ }^{1} \mathrm{H}$ NMR (DMSO): $\delta 12.62(1 \mathrm{H}, \mathrm{s}, \mathrm{OH}), 7.85$ $(1 \mathrm{H}, \mathrm{d}, \mathrm{J}=15), 7.79-7.23\left(10 \mathrm{H}, \mathrm{m}\right.$, arom), $6.85(1 \mathrm{H}, \mathrm{d}, \mathrm{J}=15) .{ }^{13} \mathrm{C}$ NMR (DMSO): $\delta 165.65$, 162.61, 150. 78 (3C), 143.83, 134.42, 131.67, 131.24, 130.57, 129.42, 128.99, 127.88, 127.18, 118.45, 95.13. Anal. Calcd. for $\mathrm{C}_{18} \mathrm{H}_{13} \mathrm{NO}_{3}$ : C, 74.23; H, 4.46; N, 4.81\%. Found : C, 73.98; H, 4.35; N, $4.59 \%$.

5-Benzyl-4-hydroxy-2-phenyl-6H-1,3-oxazin-6-one (5b). 40 g. pale yellow crystals, yield 72\%, mp 212-214 ${ }^{\circ} \mathrm{C} . \mathrm{MS}, \mathrm{m} / \mathrm{z}$ (relative intensity \%): 279 (70, parent peak), 251 (32), 131 (45), 118 (58), 91 (100, base peak), 77(21). IR (KBr): 3150 (broad peak, OH), 1710, $1650 \mathrm{~cm}-1.1 \mathrm{H}$ 
NMR (DMSO): $\delta 12.74(1 \mathrm{H}, \mathrm{s}, \mathrm{OH}), 8.02--7.10(10 \mathrm{H}, \mathrm{m}$, arom), 3.71 (2H, s, benzyl protons). 13C NMR (DMSO): $\delta$ 165.23, 162.43, 160. 37 (3C), 134.15, 131.54, 130.65, 129.89, 128.48, 127.54, 127.31, 126.95, 95.25 (C5), 33.23 (CH2). Anal. Calcd. for $\mathrm{C}_{17} \mathrm{H}_{13} \mathrm{NO}_{3}$ : C, 73.11; $\mathrm{H}$, 4.65; N, $5.01 \%$. Found : C, 72.81; H. 4.78; N; $4.85 \%$.

2-Benzyl-5-phenyl-6H-1,3-oxazinone (7a). 0.42 g. White crystals, yield 76\%, mp 127-129 ${ }^{\circ} \mathrm{C}$. MS, m/z (relative intensity \%): 279 (10, parent peak), 253 (90), 135 (100, base peak), 91 (80). IR (KBr): 3250 (broad peak, $\mathrm{OH}$ ), 1752, 1740, 1660, $1610 \mathrm{~cm}-1$. Anal. Calcd. for $\mathrm{C}_{17} \mathrm{H}_{13} \mathrm{NO}_{3}$ : C, 73.11; H, 4.65; N, $5.01 \%$. Found : C, 72.84; H. 4.45; N, $4.78 \%$.

Major tautomer (2-Benzyl-4-hydroxy-5-phenyl-6H-1,3-oxazin-6-one, 7a, I). (60\%). ${ }^{1} \mathrm{H}$ NMR (DMSO): $\delta 11.24(1 \mathrm{H}, \mathrm{s}, \mathrm{OH}), 7.50-6.89(20 \mathrm{H}, \mathrm{m}$, arom $){ }^{*}, 3.38(2 \mathrm{H}, \mathrm{s}$, benzilic protons $) .{ }^{13} \mathrm{C}$ NMR (DMSO): $\delta\left(172.65,172.02,169.96,169.22, \mathrm{C}=\mathrm{O} \text { and } \mathrm{C}_{2}, \mathrm{C}_{4}\right)^{*},(136.88,134.78,134.21$, $129.98,129.88,129.43,128.62,128.53,128.52,127.96,127.10,126.63)^{*}, 94.35\left(\mathrm{C}_{5}\right)$ and 42.64 $\left(\mathrm{CH}_{2}\right)$. * For two tautomers

Minor tautomer (2-benzyl-5-phenyl-4H-1,3-oxazine-4,6 (5H)-dione 7a, II). (40\%). ${ }^{1} \mathrm{H}$ NMR (DMSO): $\delta 5.19$ (1H, s, malonyl-H on $\mathrm{C}_{5}$ ), 3.80 (benzilic protons). ${ }^{13} \mathrm{C}$ NMR (DMSO): $\delta 59.22$ $\left(\mathrm{C}_{5}\right), 43.32\left(\mathrm{CH}_{2}\right)$.

2-Methyl-5-phenyl-6H-1,3- oxazinone (7b). 0.28 g pale yellow crystals, yield 70\% $\%$, 126 $128^{\circ} \mathrm{C} . \mathrm{MS}, \mathrm{m} / \mathrm{z}$ (relative intensity\%): 203 (30, parent peak), 175 (100, base peak), 118 (40), 77 (28). IR (KBr): 3300 (broad peak, OH), 1760, 1735, 1660, $1530 \mathrm{~cm}^{-1}$. Anal. Calcd. for $\mathrm{C}_{11} \mathrm{H}_{9} \mathrm{NO}_{3}$ : C, 65.02; H, 4.43; N, $6.89 \%$. Found : C, 64.83; H. 4.35; N; $6.69 \%$.

Major tautomer (4-hydroxy-2-methyl-5-phenyl-6H-1,3-oxazin-6-one, 7b, I) (55\%) ${ }^{1} \mathrm{H} \mathrm{NMR}$ (DMSO): $\delta 12.50(1 \mathrm{H}, \mathrm{s}, \mathrm{OH}), 7.48-7.21(10 \mathrm{H}, \mathrm{m}$, arom $){ }^{*}, 1.80\left(3 \mathrm{H}, \mathrm{s}\right.$, methyl protons). ${ }^{13} \mathrm{C}$ NMR (DMSO): $\delta$ (171.92, 168.70, 167.55, 165.01, 161.15, $\mathrm{C}=\mathrm{O}$ and $\left.\mathrm{C}_{2}, \mathrm{C}_{4}\right)^{*}, 93.56\left(\mathrm{C}_{5}\right), 21.32$ $\left(\mathrm{CH}_{3}\right) . *$ For two tautomers

Minor tautomer (2-methyl-5-phenyl-4H-1,3-oxazine-4,6 (5H)-dione, 7b, II) (45\%) ${ }^{1} \mathrm{H}$ NMR (DMSO): $\delta 5.13\left(1 \mathrm{H}, \mathrm{s}\right.$, malonyl-H on $\left.\mathrm{C}_{5}\right), 2.36$ (methyl protons). ${ }^{13} \mathrm{C}$ NMR (DMSO): $\delta 59.95$ $\left(\mathrm{C}_{5}\right), 22.83\left(\mathrm{CH}_{3}\right)$.

\section{Acknowledgements}

The authors express appreciation to the Shahid Bahonar University of Kerman Faculty Research Committee and Islamic Azad University of Yazd for their support to this investigation.

\section{References and Footnotes}

1. Saidi, K.; Tidwell, T. T. ARKIVOC 2001, 100.

2. Freiermuth, B.; Wentrup, C. J. Org .Chem. 1991, 56, 2286.

3. Sheibani, H.; Bornhardt, P. V.; Wentrup, C. J. Org. Chem. 2005, in press. 
4. Wentrup, C.; Heilmayer, W.; Kollenz, G. Synthesis. 1994, 1219

5. Wallfisch, B. C.; Belaj, F.; Wentrup, C.; Kappe, C. O.; Kollenz, G. J. Chem. Soc, Perkin Trans 1 2002, 599.

6. Brown, D. G.; Hoye, T, R.; Brisbois, R. G. J. Org. Chem. 1998, 63, 1630.

7. Potts, K. T.; Ehlinger, R.; Kanemasa, S. J. Org. Chem. 1980, 45, 2474.

8. Ried, W.; Nenninger, H. Synthesis 1990, 167.

9. Potts, K.T.; Dery, M. O.; Kullnig, R. J. Chem. Soc., Chem. Commun. 1987, 840

10. Sheibani, H.; Islami, M. R.; Hojatollah Khabazzadeh; Saidi, K Tetrahedron. 2004, 60, 5932.

11. Sheibani, H.; Lari, J.; Islami, M. R.; Saidi, K. Russ. Chem. Bull. 2003, 55, 1411.

12. Saidi, K.; Sheibani, H. Synth. Commun. 2001, 31, 1809.

13. Ollis, W. D.; Stanforth, S. P.; Ramsden, C. Tetrahedron 1985, 41, 2239.

14. Potts, K. T.; Elinger, R.; Nichols, W. W. J. Org. Chem. 1975, 40, 2596.

15. Potts, K. T.; Murphy, P. M.; Kuehnling, W. R. J.Org. Chem. 1988, 53, 2889.

16. Nakanishi, S.; Butler, K. Org. Prep. Precd. Int. 1975, 7(4), 155.

17. Beilin, V. G.; Gindin, V. A.; Dashkevich, L. B. Soedin. 1976, 8, 1042.

18. Goerdeler, J.; Horstmann, H. Chem. Ber. 1960, 93, 671.

19. Finnerty, J.; Andraos, J. ; Yamamoto, Y. ;Wong, M.W. ; Wentrup, C. J. Am. Chem. Soc. 1998, 120, 1701.

20. Islami, M. R.; Mollazehi, F.; Badiei, A.; Sheibani, H. ARKIVOC 2005, (xv), 25.

21. Ziegler, E.; Steiner, E. Monatsh. Chem. 1964, 95, 147. 